\title{
Changes in Nucleotide Pools during Sporulation of Streptomyces griseus in Submerged Culture
}

\author{
By KOZO OCHI \\ Exploratory Research Laboratories, Fujisawa Pharmaceutical Co. Ltd., 5-2-3 Tokodai, \\ Toyosato-machi, Tsukuba-gun, Ibaraki 300-26, Japan
}

(Received 6 April 1987; revised 19 June 1987)

\begin{abstract}
Streptomyces griseus strain 13189 produced a large number of submerged spores in response to nitrogen-mediated nutritional shift-down. The pool size of ppGpp increased immediately after shift-down and was accompanied by a dramatic decrease in the GTP pool. In contrast, nutritional shift-down of a relaxed (rel) mutant derived from strain 13189 resulted in a slight increase in ppGpp pool size, a less extensive decrease in GTP pool size and spore titres 10-fold less than produced by the parental strain. Addition of decoyinine, a specific inhibitor of GMP synthetase, to the rel mutant restored the sporulation frequency to the parental level. IMP dehydrogenase was competitively inhibited by ppGpp with a $K_{\mathrm{i}}$ of $0.05 \mathrm{mM}$, whereas other nucleotides were less effective inhibitors. The observed intracellular concentration of ppGpp during shift-down was sufficient to inhibit IMP dehydrogenase activity and to result in the decrease in the GTP pool. These results demonstrate that sporulation of $S$. griseus, like that of Bacillus subtilis, is nutrient-dependent and that the decrease in GTP content caused by the stringent response (ppGpp) is correlated with initiation of submerged spore formation due to amino acid starvation.
\end{abstract}

\section{INTRODUCTION}

Unlike endospore formation in the genus Bacillus, differentiation of Streptomyces spp. on agar plates consists of two processes, namely development of an aerial mycelium, and segmentation of the aerial mycelium into spores. Although Streptomyces spp. generally produce few or no spores in submerged culture, several species, including $S$. griseus, form abundant spores in submerged culture in appropriate nutritional conditions. Taking Streptomyces differentiation as a feasible model system for studying morphological and physiological differentiation of prokaryotes, the significance of the 'stringent response' in their initiation processes has been stressed (Ochi, 1986 b 1987). When bacterial cells sense amino acid deficiency the stringent response results in immediate accumulation of intracellular ppGpp and pppGpp and severe reductions in the rate of RNA synthesis and numerous other cellular reactions. The stringent response can be bypassed by introducing genes with the relaxed ( $r e l$ ) genotype (for reviews, see Cashel, 1975 and Gallant, 1979). Aerial mycelium formation of Streptomyces has been shown to be correlated with a decrease in GTP content (Ochi, 1986a). In this paper the effect of the stringent response (arising due to nutritional shift-down) on nucleotide pools is investigated further.

\section{METHODS}

Strains. Streptomyces griseus IFO 13189 , a prototrophic wild-type, was provided by the Institute of Fermentation, Osaka, Japan. A relaxed mutant no. 3-3 was derived from strain 13189 as a spontaneous thiopeptin (an analogue of thiostrepton)-resistant isolate. This mutant strain displayed the relaxed phenotype with respect to RNA synthesis and may be classified as a relC mutant in analogy with the corresponding mutant of $B$. subtilis (Smith et al., 1980). The rel mutation was apparently leaky and still produced measurable amounts of ppGpp. Details of the isolation and properties of the mutant will be reported elsewhere. 
Growth conditions. Filter-sterilized glucose/peptone medium (Kendrick \& Ensign, 1983) was used. It contained $20 \mathrm{~mm}$-glucose, $1 \%(\mathrm{w} / \mathrm{v})$ peptone (Bacto-peptone; Difco), $20 \mathrm{mM}-\mathrm{NH}_{4} \mathrm{Cl}, 50 \mathrm{mM}$-sodium-phosphate/potassium phosphate buffer (pH 7.2), $2 \mathrm{mM}-\mathrm{MgCl}_{2}, 0.5 \mathrm{~mm}-\mathrm{K}_{2} \mathrm{SO}_{4}, 0.1 \mathrm{~mm}-\mathrm{FeCl}_{3}, 0.03 \mathrm{~mm}-\mathrm{CaCl}_{2}, 0.6 \mu \mathrm{M}-\mathrm{ZnCl}_{2}, 0.12 \mu \mathrm{M}-$ $\mathrm{CuCl}_{2}, 0.1 \mu \mathrm{M}-\mathrm{MnCl}_{2}, 0.05 \mu \mathrm{M}-\mathrm{Na}_{2} \mathrm{~B}_{4} \mathrm{O}_{7}$ and $0.016 \mu \mathrm{M}-\left(\mathrm{NH}_{4}\right)_{6} \mathrm{Mo}_{7} \mathrm{O}_{24}$. Where stated, the peptone concentration was increased to $2 \%(\mathrm{w} / \mathrm{v})$. SCY medium contained $\left(1^{-1}\right)$ : soluble starch, $20 \mathrm{~g}$; Casamino acids (vitamin-free), $5 \mathrm{~g}$; and yeast extract, $4 \mathrm{~g}$ (adjusted to $\mathrm{pH} 7$ with $\mathrm{NaOH}$ ). SPY medium contained $\left(1^{-1}\right)$ : soluble starch, $30 \mathrm{~g}$; polypeptone, $30 \mathrm{~g}$; yeast extract, $2 \mathrm{~g} ; \mathrm{MgSO}_{4}$ (anhydrous), $10 \mathrm{~g} ; \mathrm{CaCl}_{2}$ (anhydrous), $50 \mathrm{mg} ; \mathrm{ZnSO}_{4} \cdot 5 \mathrm{H}_{2} \mathrm{O}$, $30 \mathrm{mg} ; \mathrm{FeSO}_{4} .5 \mathrm{H}_{2} \mathrm{O}, 25 \mathrm{mg} ; \mathrm{CuSO}_{4} .5 \mathrm{H}_{2} \mathrm{O}, 16 \mathrm{mg}$; and $\mathrm{MnSO}_{4} \cdot 4 \mathrm{H}_{2} \mathrm{O}, 12 \mathrm{mg}$ (adjusted to $\mathrm{pH} 7 \cdot 2$ with $\mathrm{NaOH}$ ). These media were sterilized by autoclaving at $120^{\circ} \mathrm{C}$ for $20 \mathrm{~min}$.

A monospore suspension ( $4 \mathrm{ml}$; about $8 \times 10^{8}$ spores) of $S$. griseus strain 13189 , prepared by scraping the spores from a slant and blending in a vortex mixer with glass beads, was inoculated into glucose/peptone medium $(50 \mathrm{ml}$ in a $250 \mathrm{ml}$ flask) or into SCY medium (for rel mutant 3-3) and incubated as indicated at $30^{\circ} \mathrm{C}$ on a rotary shaker (230 r.p.m.).

Continuous culture. Spores of strain 13189 were inoculated and grown in glucose/peptone medium as described above. At the mid-exponential growth phase ( $8 \mathrm{~h}$ with $2 \%$ peptone, $12 \mathrm{~h}$ with $0.02 \%$ peptone), the culture was diluted twice with fresh glucose/peptone medium and incubation was continued. Whenever the culture reached about twice the original cell mass it was diluted twofold in the same medium. Thus, cell growth was kept nearly in the mid-exponential phase throughout the long-term cultivation.

Nutritional shift-down. Strain 13189 was grown in glucose/peptone medium. After $8 \mathrm{~h}$ cultivation, cells were collected on a sterilized filter paper (diameter $9 \mathrm{~cm}$, Toyo Roshi no. 2), and rapidly transferred to the original volume of fresh glucose/peptone medium but lacking peptone and $\mathrm{NH}_{4} \mathrm{Cl}$; incubation was then continued for $48 \mathrm{~h}$ with shaking. All the procedures were done under sterile conditions. Biomass (dry cell wt) increased 20-30\% during the early $20 \mathrm{~h}$ incubation. [Although deprivation of peptone alone may be enough for nutritional shiftdown, both peptone and $\mathrm{NH}_{4} \mathrm{Cl}$ were, omitted according to the method of Kendrick \& Ensign (1983)]. As the relaxed mutant 3-3 grew somewhat slowly in glucose/peptone medium, it was precultured in SCY medium for $15 \mathrm{~h}$, the cells collected by centrifugation and resuspended in the original volume of glucose/peptone medium. After $3 \mathrm{~h}$ incubation with shaking, the cells were nutritionally shifted down as described for strain 13189 .

Assay of submerged spores. Unlike endospores of the genus Bacillus, spores of $S$. griseus are not highly resistant to heat, but are resistant to sonication (Kendrick \& Ensign, 1983). Therefore, spore titres were determined by direct counting in a Petroff-Hauser counting chamber using phase contrast optics after sonication of cultured broth for $5 \mathrm{~min}$. Sonication dispersed spore clumps and spores were easily counted as refractile bodies.

Assay of nucleotide pools. The intracellular concentrations of nucleoside triphosphates, including ppGpp and pppGpp, were assayed by HPLC on a column of Partisil PXS 10 SAX (Whatman; length $25 \mathrm{~cm}$; void volume $3.02 \mathrm{ml}$ ) after extraction with $1 \mathrm{M}$-formic acid (Ochi et al., 1981; Ochi, 1986 b). For assay of IMP by HPLC, the sample was applied to the column which had previously been washed with $45 \mathrm{ml} 0.05 \mathrm{M}-\mathrm{H}_{2} \mathrm{SO}_{4}$ followed with $15 \mathrm{ml} 0.5 \mathrm{M}-\mathrm{KH}_{2} \mathrm{PO}_{4}+0.5 \mathrm{M}-\mathrm{Na}_{2} \mathrm{SO}_{4}$ (adjusted to pH 5.4 with $\mathrm{KOH}$ ), and then with $100 \mathrm{ml} 7 \mathrm{mM}^{-} \mathrm{KH}_{2} \mathrm{PO}_{4}$ (adjusted to $\mathrm{pH} 4$ with $\mathrm{H}_{3} \mathrm{PO}_{4}$ ). IMP was eluted with $7 \mathrm{mM}-\mathrm{KH}_{2} \mathrm{PO}_{4}$ at a flow rate of $1.5 \mathrm{ml} \mathrm{min}^{-1}$ (retention time $22 \mathrm{~min}$ ). For assay of GMP and XMP, the sample was applied to the column which had previously been washed with $45 \mathrm{ml} 0.05 \mathrm{M}-\mathrm{H}_{2} \mathrm{SO}_{4}$ followed with $100 \mathrm{ml} 0.05 \mathrm{M}-\mathrm{KH}_{2} \mathrm{PO}_{4}+0.05 \mathrm{M}-\mathrm{Na}_{2} \mathrm{SO}_{4}$ (adjusted to pH 5.4 with $\mathrm{KOH}$ ). GMP and XMP were eluted with $0.05 \mathrm{M}-\mathrm{KH}_{2} \mathrm{PO}_{4}+0.05 \mathrm{M}-\mathrm{Na}_{2} \mathrm{SO}_{4}$ (pH 5.4) at a flow rate of $1.5 \mathrm{ml} \mathrm{min}^{-1}$. The retention times for GMP and XMP were $5.7 \mathrm{~min}$ and $11 \mathrm{~min}$ respectively. The amounts of nucleotides present in different cultures were expressed relative to the cell dry wt measured at the time of harvesting i.e. pmol or nmol (mg dry wt $)^{-1}$. The cell dry wt was determined as described by Ochi (1986b).

Intracellular water content. This was determined as described by Freese et al. (1984) with some modifications. $S$. griseus 13189 was grown in glucose/peptone medium for $7 \mathrm{~h}$ and three $7 \mathrm{ml}$ portions were rapidly distributed into centrifuge tubes containing [ $\left.\mathrm{U}^{-14} \mathrm{C}\right]$ leucine $[1 \mu \mathrm{Ci}(37 \mathrm{kBq})$; New England Nuclear] and $20 \mathrm{mg}$ unlabelled leucine. After centrifugation $(5000 \mathrm{~g}, 5 \mathrm{~min}$ ) the supernatant was collected (supernatant $\mathrm{A}$ ). The cells were resuspended in $10 \mathrm{ml} 20 \mathrm{~mm}$ unlabelled leucine, centrifuged immediately $(5000 \mathrm{~g}, 5 \mathrm{~min}$ ) and the supernatant again collected (supernatant B). The tubes were weighed, dried to constant weight in a vacuum desiccator and reweighed. This difference in weight gave the water content in the pellets. The radioactivity present in $1 \mathrm{ml}$ samples of supernatants A and B was determined in a liquid scintillation counter with Aquasol (New England Nuclear) as scintillation fluid. The interstitial water volume was given as (c.p.m. in supernatant B $\times 10) /($ c.p.m. in supernatant A). The intracellular water volume was estimated from the difference between the total and interstitial water volumes. The average volume was $3 \cdot 3 \mu \mathrm{l}(\mathrm{mg} \text { cell dry wt })^{-1}$.

Assay of IMP dehydrogenase and GMP synthetase. Cells of $S$. griseus 13189 grown in 1 litre of SPY medium for $10 \mathrm{~h}$ (late-exponential phase) were collected by filtration (Toyo Roshi no. 2) and washed with $300 \mathrm{ml}$ of chloramphenicol solution $\left(20 \mu \mathrm{g} \mathrm{ml}^{-1}\right)$. In a typical experiment, $17 \mathrm{~g}$ of cell paste were obtained. The cells were resuspended to a volume of $45 \mathrm{ml}$ in $10 \mathrm{mM}$-Tris/ $\mathrm{HCl}$ buffer $(\mathrm{pH} \mathrm{7.4)} \mathrm{containing} 1 \mathrm{~mm}$-mercaptoethanol and $20 \mu \mathrm{g}$ chloramphenicol $\mathrm{ml}^{-1}$. The cells were disrupted by sonication for 1-2 $\mathrm{min}$ in an ice-cold bath, followed by centrifugation $(15000 \mathrm{~g}, 15 \mathrm{~min})$ to remove cell debris. This crude cell extract was used for assay of GMP 
synthetase activity; the specific activity was $0.6 \mathrm{nmol} \mathrm{GMP} \min ^{-1}(\mathrm{mg} \text { protein })^{-1}$ in the presence of $1 \mathrm{mM}-\mathrm{XMP}$ (see below). The specific activity of IMP dehydrogenase was $2.2 \mathrm{nmol} \mathrm{NADH} \mathrm{min}^{-1}$ (mg protein) ${ }^{-1}$ in the presence of $1 \mathrm{mM}$-IMP. No IMP dehydrogenase activity was detected if the cell extract was prepared by lysozyme treatment, or if old cells (e.g. $24 \mathrm{~h}$ culture) were used to prepare the cell extract. IMP dehydrogenase was partially purified as follows. Polyethyleneimine (Polymin P, BRL) $(2 \mathrm{ml}, 2.5 \%$ w/v) was added slowly to $50 \mathrm{ml}$ of the crude cell extract to precipitate nucleic acid and inactivate protein. The precipitate was removed by centrifugation $(15000 \mathrm{~g}, 10 \mathrm{~min})$ and discarded. Ammonium sulphate was added slowly to the supernatant with stirring to give $66 \%$ saturation. After standing for $1 \mathrm{~h}$ in an ice-cold bath, the precipitate was collected by centrifugation $(15000 \mathrm{~g}$, $40 \mathrm{~min}$ ), dissolved in $7.5 \mathrm{ml}$ deionized water and dialysed for $15 \mathrm{~h}$ against $5110 \mathrm{mM}$-Tris/ $\mathrm{HCl}$ buffer $(\mathrm{pH} \mathrm{7.4)}$ containing $1 \mathrm{~mm}$-mercaptoethanol. A small amount of precipitate formed during dialysis was removed by centrifugation and discarded. The supernatant $(30 \mathrm{ml})$ thus obtained was used for the IMP dehydrogenase assay. It contained $16 \mathrm{mg}$ protein $\mathrm{ml}^{-1}$ and had a specific activity of $5.8 \mathrm{nmol} \mathrm{NADH} \mathrm{min}{ }^{-1}\left(\mathrm{mg}\right.$ protein) ${ }^{-1}$, a 2.7 -fold increase in specific activity and $40 \%$ increase in total activity in comparison with the original crude extract. All the purification procedures were done at $0-4{ }^{\circ} \mathrm{C}$.

IMP dehydrogenase was assayed as described by Magasanik (1963) with the following modifications. The reaction was done in a quartz cell with a $1 \mathrm{~cm}$ path in a $0.5 \mathrm{ml}$ reaction volume containing $50 \mu 11 \mathrm{M}-\mathrm{Tris} / \mathrm{HCl}$ buffer (pH 8.0), $15 \mu \mathrm{l} 100 \mathrm{~mm}$ reduced glutathione, $15 \mu \mathrm{l} 1 \mathrm{M}$-ammonium sulphate, $50 \mu \mathrm{l} 40 \mathrm{mM}-\mathrm{NAD}^{+}, 50 \mu \mathrm{l}$ enzyme solution and disodium IMP at the indicated concentration. The reaction was started by addition of IMP and followed at $30^{\circ} \mathrm{C}$ for $10 \mathrm{~min}$ by measuring the increase in absorbance at $340 \mathrm{~nm}$. The initial velocity of the reaction was determined during the first $3 \mathrm{~min}$ of reaction. The partially purified IMP dehydrogenase could be stored at $-15^{\circ} \mathrm{C}$ at least for $7 \mathrm{~d}$ without loss of activity, but fresh enzyme preparations were always used for each experiment.

GMP synthetase was assayed by the method of Magasanik (1963), by measuring the increase in absorbance at $290 \mathrm{~nm}$ (GMP formation) after perchloric acid treatment. The reaction mixture contained $40 \mu 11 \mathrm{M}-\mathrm{Tris} / \mathrm{HCl}$ buffer (pH 8.5), $20 \mu \mathrm{l} 50 \mathrm{mM}$-ATP, $10 \mu 10.4 \mathrm{M}-\mathrm{MgCl}_{2}, 40 \mu \mathrm{l} 2 \mathrm{M}$-ammonium sulphate, $25 \mu 110 \mathrm{mM}-\mathrm{XMP}, 100 \mu 1$ enzyme solution and deionized water to a final volume of $250 \mu \mathrm{l}$. The reaction was done at $30^{\circ} \mathrm{C}$ for $30 \mathrm{~min}$ in the presence and absence of XMP.

Reproducibility. The experiments shown in each Figure were repeated two or three times to confirm reproducibility; representative results are presented.

\section{RESULTS}

\section{Induction of sporulation by decoyinine}

In order to examine the effect of decoyinine, a specific inhibitor of GMP synthetase, on the induction of sporulation it was necessary to find a medium in which sporulation is normally suppressed. In glucose/peptone medium (Kendrick \& Ensign, 1983) containing $2 \%(\mathrm{w} / \mathrm{v})$ peptone, $S$. griseus 13189 grew well, but sporulated poorly (Fig. 1). The sporulation frequency was related to the nutrients present in the medium: if the amount of peptone was reduced to $0.5 \%, 0.2 \%$ or $0.02 \%$, the cells sporulated well producing $4 \times 10^{8}, 1.2 \times 10^{9}$ and $1.6 \times 10^{9}$ spores $\mathrm{ml}^{-1}$, respectively after $48 \mathrm{~h}$ incubation. More convincing evidence for the significance of nutrient limitation was shown by continuous cultivation, where the cell physiology could be maintained relatively constant (although micro-colonies formed during continuous culture). When cells were continuously cultivated in glucose/peptone medium containing $1 \%$ or $2 \%$ peptone in mid-exponential growth phase (see Methods), they produced only $2-4 \times 10^{6}$ spores $\mathrm{ml}^{-1}$ during $60 \mathrm{~h}$ cultivation. In contrast, relatively high spore titres (about $3 \times 10^{8} \mathrm{ml}^{-1}$ ) were observed if cells were continuously cultivated in the same medium containing $0.02 \%$ peptone. To eliminate the possibility that those cells which continued to grow with $2 \%$ peptone had become sporulation deficient, a portion of the final subculture was diluted and plated, and seven colonies were isolated. Cells of these isolates grown for $48 \mathrm{~h}$ in glucose/peptone medium containing $0.02 \%$ peptone all sporulated normally, producing spore titres $\left(0.9-1.7 \times 10^{9} \mathrm{ml}^{-1}\right)$ similar to the original strain. Cells growing exponentially in media containing different amounts of peptone showed marked differences in their intracellular nucleotide pool size; this was especially pronounced for GTP pools, which were 910-1250 pmol and 4200-4750 pmol (mg dry wt $)^{-1}$ for cells growing with $0.02 \%$ and $2 \%$ peptone, respectively.

In growth conditions which normally suppress sporulation, cells could be induced to sporulate if treated with decoyinine, producing high spore titres at $10-15 \mathrm{~h}$ (Fig. 1). The optimum effect 


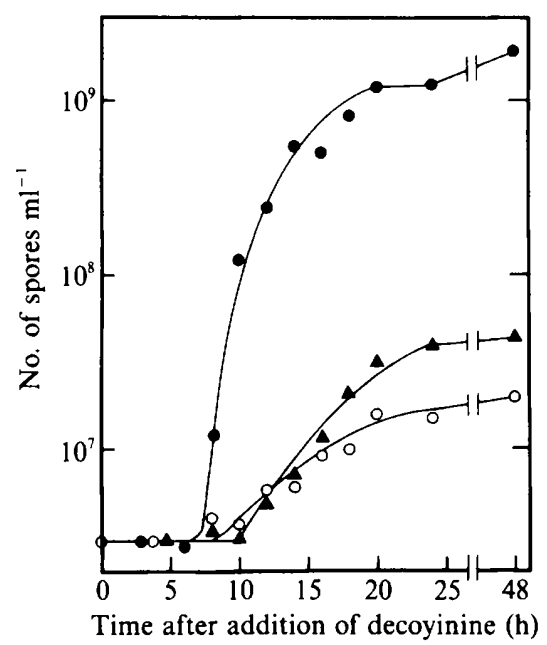

Fig. 1. Induction of submerged spore formation in $S$. griseus by decoyinine. S. griseus 13189 was grown in glucose/peptone medium containing $2 \%$ peptone and after $8 \mathrm{~h}$ incubation to mid-exponential phase decoyinine $(2 \mathrm{mM})$ or $A$-factor $\left(2 \mu \mathrm{g} \mathrm{m} \mathrm{m}^{-1}\right)$ was added. $O$, Plus decoyinine; $\Delta$, plus $A$-factor; $O$, control.

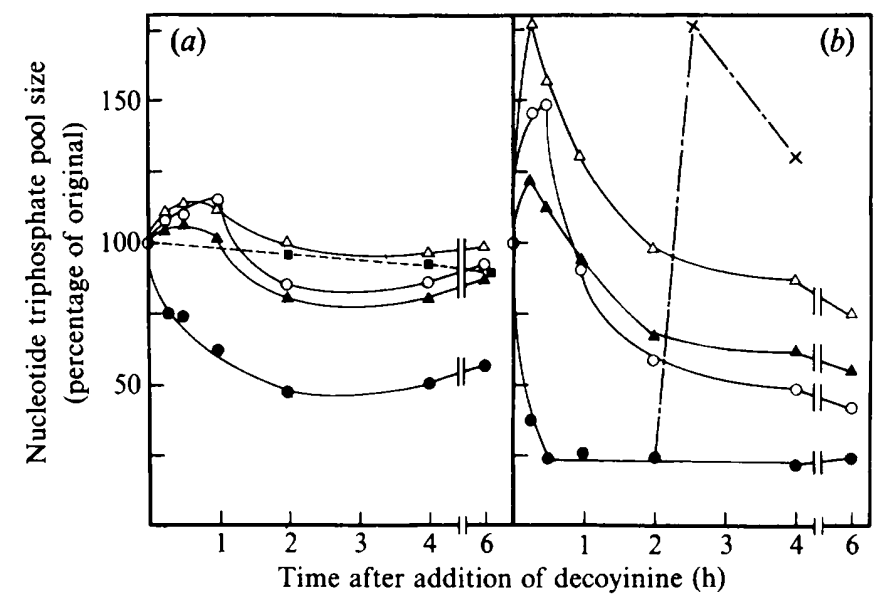

Fig. 2. Changes in the intracellular pools of nucleoside triphosphates after addition of decoyinine. Cells of $S$. griseus 13189 were treated with $0.5 \mathrm{~mm}(a)$ or $2 \mathrm{mM}(b)$ decoyinine as described for Fig. 1 . The nucleotide contents at zero time, determined as described in Methods, of GTP, ATP, UTP and CTP were $4 \cdot 17,11 \cdot 7,4.40$ and $2.49 \mathrm{nmol}(\mathrm{mg} \mathrm{dry} \mathrm{wt})^{-1}$ respectively. The sporulation frequencies determined microscopically after $30 \mathrm{~h}$ incubation were $60 \%$ with $0.5 \mathrm{~mm}$-decoyinine and nearly $100 \%$ with $2 \mathrm{mM}$ decoyinine. , GTP; O, ATP; $\triangle$, UTP; $\triangle$, CTP; $\mathbf{n}$, GTP in absence of decoyinine; X, plus $4 \mathrm{mM}-$ guanosine at $2 \mathrm{~h}$.

was obtained at $0.5 \mathrm{~mm}$-decoyinine (with respect to spore titre) or $2 \mathrm{~mm}$-decoyinine (with respect to sporulation frequency). The intracellular GTP pool was 2-4-fold lower, without an increase in ppGpp, $1 \mathrm{~h}$ after decoyinine addition (Fig. 2). The pool size of XMP (not shown) increased 70fold during the $2 \mathrm{~h}$ period after addition of $2 \mathrm{mM}$-decoyinine, indicating that decoyinine inhibited GMP synthetase activity. A-factor ( $2 S$-isocapryloyl- $3 S$-hydroxymethyl- $\gamma$-butyrolactone), an autoregulating factor produced by $S$. griseus (Khokhlov, 1986), marginally stimulated sporulation in similar experimental conditions (Fig. 1).

\section{Commitment to sporulation}

Decoyinine-induced sporulation was completely inhibited by concomitant addition of guanosine. Commitment to sporulation, beyond which sporulation occurs normally even in the 


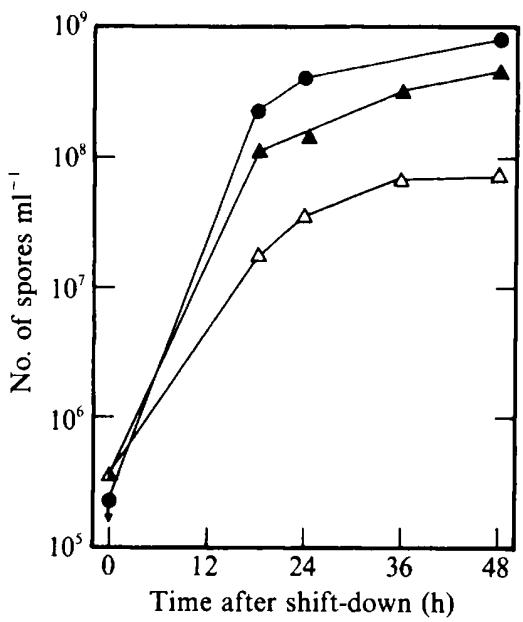

Fig. 3. Induction of submerged spore formation of $S$. griseus 13189 and strain 3-3 (rel) after nutritional shift-down. Cells were grown to mid-exponential phase in glucose/peptone medium containing $1 \%$ peptone and transferred to fresh glucose/peptone medium lacking peptone and $\mathrm{NH}_{4} \mathrm{Cl}$ as described in Methods. The arrow below the symbol indicates a spore titre $<2 \times 10^{5} \mathrm{ml}^{-1}$. O, Strain $13189 ; \triangle$, strain $3-3 ; \Delta$, strain 3-3 plus 2 mM-decoyinine.

presence of guanosine, was determined by inducing sporulation with 2 mM-decoyinine as described in Fig. 1 and adding $4 \mathrm{~mm}$-guanosine at various times. The extent of sporulation observed after $20 \mathrm{~h}$ incubation was unaffected if guanosine was added $5 \mathrm{~h}$ or more after decoyinine. Adding guanosine also restored the GTP pool to its original size (Fig. 2). Thus, as for B. subtilis (Lopez et al., 1979; Ochi et al., 1981), initiation of submerged spore formation by $S$. griseus can be correlated with an intracellular metabolic event, i.e. a decrease in GTP content. Although the sporulation induction procedure in liquid culture may not reflect that seen on solid medium, the mechanism of initiation of submerged spore formation was further analysed with another sporulation induction method.

\section{Induction of sporulation by nutritional shift-down}

Kendrick \& Ensign (1983) reported a method for initiation of sporulation of $S$. griseus by transferring cells from a nutritionally rich to a nutritionally poor medium. Cells of strain 13189 $\left(\mathrm{rel}^{+}\right)$and 3-3 ( rel) were grown to mid-exponential phase in glucose/peptone medium, harvested by filtration and immediately resuspended in the same volume of fresh glucose/peptone medium but lacking peptone and $\mathrm{NH}_{4} \mathrm{Cl}$, and then cultured for $48 \mathrm{~h}$. The rel cells produced a large number of spores by $24 \mathrm{~h}$, whereas the rel cells produced significantly fewer (Fig. 3). The changes in the intracellular nucleotide pool following shift-down were therefore examined. The $\mathrm{rel}^{+}$cells accumulated high levels of ppGpp immediately after shift-down and there was an accompanying dramatic decrease in the GTP pool (Fig. $4 a$ ). In contrast, rel cells accumulated 10-fold less ppGpp than the $\mathrm{rel}^{+}$strain and the decrease in the GTP pool was also less extensive (Fig. $4 b$ ). Deprivation of peptone may temporarily result in a severe amino acid deficiency, leading to an increase in the fraction of uncharged tRNA and thus an accelerated rate of ppGpp synthesis in $\mathrm{rel}^{+}$but not in rel cells, by analogy with the mechanism of ppGpp synthesis in $E$. coli (Gallant, 1979). Accumulation of pppGpp (not shown) was at most $10 \%$ of that of ppGpp in both rel and rel+ strains. The decreased ability of the rel strain to sporulate was largely restored by adding $2 \mathrm{~mm}$-decoyinine (Fig. 3), without a corresponding increase in ppGpp. Thus, the accentuated decrease in GTP content in $\mathrm{rel}^{+}$cells is associated with their increased sporulation frequency. In order to establish causal links between increase in ppGpp and decrease in GTP enzymic studies concerning de novo purine synthesis were done. 


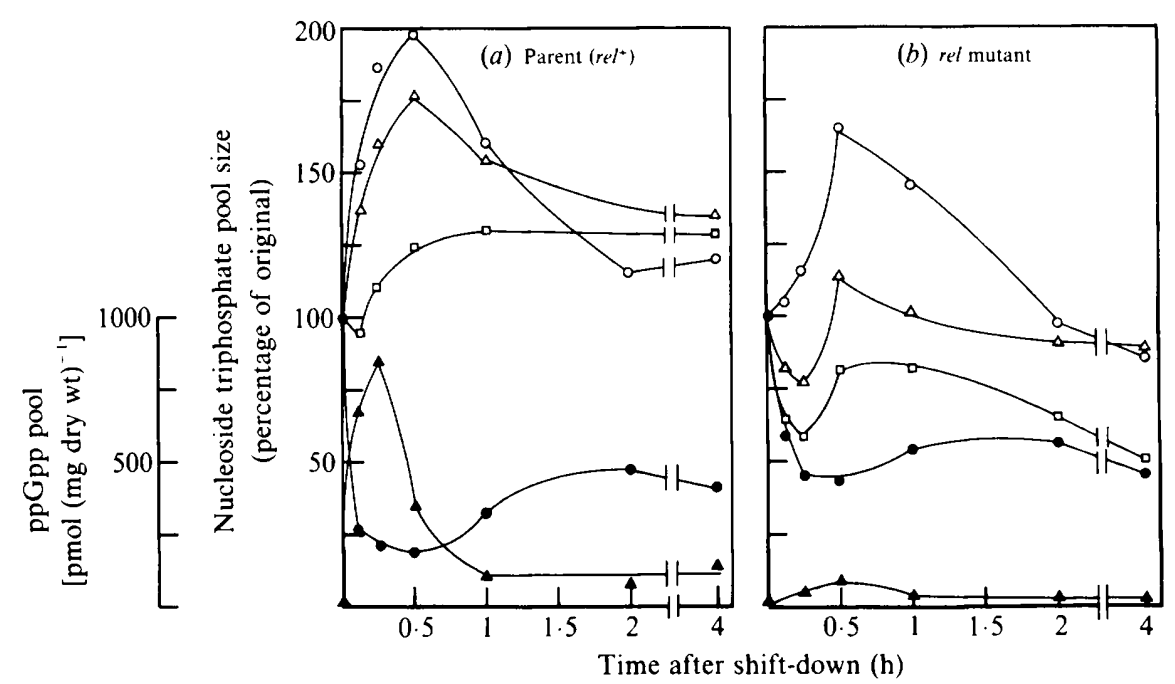

Fig. 4. Changes in the intracellular pools of nucleoside triphosphates and ppGpp after nutritional shiftdown. Cells of strain $13189(a)$ or strain 3-3 (b) were shifted down as described in Fig. 3. Just before transfer nucleotide pools, determined as described in Methods, of GTP, ATP, UTP and CTP were 3.37, $8.40,3.10$ and 1.89 (strain 13189) and 4.04, 8.56, 5.19 and 2.92 (strain 3-3) nmol (mg dry wt) ${ }^{-1}$ respectively. GTP; $\triangle$, ppGpp; O, ATP; $\square$, UTP; $\triangle$, CTP.

\section{Mechanism of ppGpp control of GTP synthesis}

In E. coli (Gallant et al., 1971), ppGpp is a strong inhibitor of IMP dehydrogenase, the first enzyme of the pathway leading to GTP. The activity of $S$. griseus IMP dehydrogenase was measured with various concentrations of IMP $(0.02-2 \mathrm{mM})$ in the presence or absence of $0.3 \mathrm{mM}-$ ppGpp or GMP. ppGpp was a strong competitive inhibitor of $S$. griseus IMP dehydrogenase, as determined by a Lineweaver-Burk plot which showed the $K_{\mathrm{m}}$ value for IMP to be $0.072 \mathrm{mM}$. The $K_{\mathrm{i}}$ value for ppGpp was $0.056 \mathrm{mM}$, implying that it was a much stronger inhibitor than GMP $\left(K_{\mathrm{i}}\right.$ $0.32 \mathrm{mM}$ ), the most potent nucleotide inhibitor in E. coli (Powell et al., 1969). In order to confirm the type of inhibition and the $K_{\mathrm{i}}$ value IMP dehydrogenase activity was measured with a fixed concentration of IMP (either $0 \cdot 1 \mathrm{mM}$ or $0.3 \mathrm{mM}$ ) and various concentrations of ppGpp (0-2 mM). The resulting Dixon plots (Dixon \& Webb, 1964) showed straight lines up to 2 mM-ppGpp and demonstrated competitive inhibition with a $K_{\mathrm{i}}$ of $0.05 \mathrm{mM}$, in agreement with that estimated from the Lineweaver-Burk plot. The effects of various purine and pyrimidine compounds on IMP dehydrogenase were tested at a fixed concentration of IMP $(0.2 \mathrm{mM})$, with and without possible effectors ( $1 \mathrm{mM})$. The inhibition observed was, in order of effectiveness: ppGpp $(85 \%)$, ATP $(60 \%)$, XMP $(51 \%)$, ADP (36\%), GMP $(31 \%)$, GTP $(10 \%)$ and AMP $(6 \%)$. UTP, CTP, guanine and guanosine had virtually no effect. Since many regulating enzymes, including IMP dehydrogenase, become desensitized upon chemical or physical shock (Wu \& Scrimgeour, 1973), the sensitivity of IMP dehydrogenase to inhibition by ppGpp and GMP was also examined using crude cell extract instead of partially purified enzyme: each inhibitor produced virtually the same inhibition as above. Thus, $\mathrm{ppGpp}$ was a very strong inhibitor in $S$. griseus. It is, however, surprising that ATP and ADP were more inhibitory than GMP. Ishii \& Shiio (1968) reported that ATP was a strong inhibitor of $B$. subtilis IMP dehydrogenase at a high, but not a low, concentration of $\mathrm{KCl}$. Therefore, the inhibition was also examined at a low concentration ( $3 \mathrm{mM}$ ) of ammonium sulphate, which replaced $\mathrm{KCl}$ in this study; the inhibition by ATP and ADP was reduced to only $15-20 \%$ inhibition, whereas ppGpp, XMP and GMP all still showed strong inhibition with only slight reductions. If the ammonium sulphate concentration was further reduced i.e. to $1 \mathrm{mM}$, both ATP and ADP were no longer inhibitory.

In contrast with IMP dehydrogenase, 1-2 mM-ppGpp did not inhibit GMP synthetase, which can also produce GTP. 


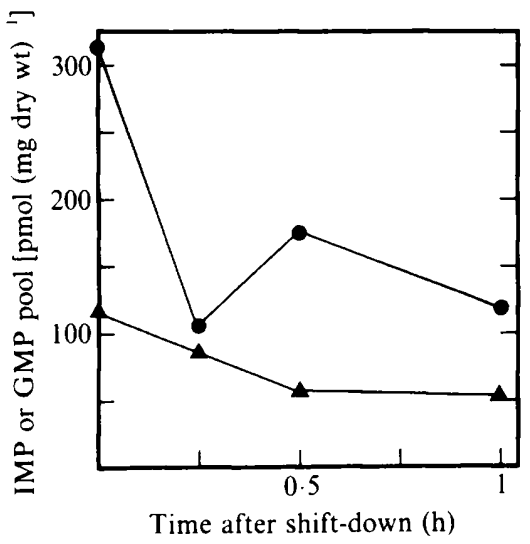

Fig. 5. Changes in the intracellular pools of IMP and GMP after nutritional shift-down. Cells of $S$. griseus strain 13189 were shifted down as described in Fig. 3 and IMP and GMP were determined as described in Methods. $\mathrm{O}$ IMP; $\triangle$, GMP.

\section{Inhibition of IMP dehydrogenase in vivo}

The extent of inhibition of enzyme activity depends on the concentrations of both the substrate and the inhibitor. Therefore, to estimate the significance of $\mathrm{ppGpp}$ in vivo, it was necessary to determine the intracellular levels of IMP and ppGpp. The pool sizes of IMP before and after shift-down were measured (Fig. 5). The intracellular water content was found to be $3.3 \mu \mathrm{l}$ (mg cell dry wt) ${ }^{-1}$. Thus, the concentration of IMP just before shift-down was calculated to be $0.095 \mathrm{mM}$, a value slightly higher than the $K_{\mathrm{m}}$ for IMP dehydrogenase. The maximum concentration of ppGpp, observed $15 \mathrm{~min}$ after shift-down, was $0.256 \mathrm{mM}$ (five times greater than the $K_{\mathrm{i}}$ value). This concentration of $\mathrm{ppGpp}$ would inhibit IMP dehydrogenase activity by $69 \%$ in the presence of 0.095 mM-IMP. The decreased level of ppGpp, observed $1-4 \mathrm{~h}$ after shiftdown, would still inhibit this activity by $28 \%$ and thus could account for the decreased GTP pool (see Fig. $4 a)$. The maximum ppGpp pool observed in rel cells $(0.026 \mathrm{mM})$ would inhibit IMP dehydrogenase activity by only $17 \%$. This may account for the reduced decrease in GTP in rel cells. Although the ATP pool size was very high before and after shift-down (2.5-4.9 mM), inhibition by ATP may not be physiologically significant as it caused slight or no inhibition at physiological concentrations of ammonium sulphate. Inhibition by XMP and GMP was also not significant due to their low concentrations $(\leqslant 0.03 \mathrm{mM})$. Thus, in the experimental conditions described, ppGpp inhibition of IMP dehydrogenase activity is a crucial event for regulating the synthesis of GTP.

\section{DISCUSSION}

The purpose of this study was to relate GTP pool size to initiation of sporulation of $S$. griseus and to determine the biochemical basis of changes in the GTP pool. Submerged spore formation of $S$. griseus depended on nutritional status and the decrese in GTP was correlated with initiation of submerged spore formation. Aerial mycelium formation of this organism on agar plates is also nutrient-dependent (unpublished). The observed decrease in GTP content after shift-down depended largely on the ppGpp inhibition of IMP dehydrogenase. It is noteworthy that IMP did not accumulate, but decreased after shift-down (Fig. 5). This implies that ppGpp also inhibited an early step in the purine pathway, as suggested for $E$. coli (Gallant et al., 1971), or alternatively IMP could be channelled into ATP formation. Since the IMP pool size before shift-down was only slightly higher than its $K_{\mathrm{m}}$ value, a decrease in IMP pool size would affect the reaction velocity of IMP dehydrogenase. A decrease in IMP pool size would also result in an increased inhibition of IMP dehydrogenase by ppGpp since ppGpp is a competitive inhibitor against IMP. Thus, ppGpp could produce synergistic effects in reducing GTP synthesis. The 
GTP content may be reduced not only by ppGpp inhibition of enzyme activities, but also by a decrease in purine precursor synthesis. Since the nutritional shift-down technique used results in depletion of all nitrogen sources in the medium, curtailment of purine nucleotide synthesis due to nitrogen deficiency may be partially responsible for the observed decrease in GTP pool size. This effect may be more pronounced at later times after shift-down. It may also account for the relatively low GTP pool size observed $1-4 \mathrm{~h}$ after shift-down of the rel strain, which was lower than would be expected solely from ppGpp inhibition of IMP dehydrogenase (see Fig. $4 b$ ). Since pool sizes of ATP and CTP also changed markedly under sporulation conditions (Figs $2 b$ and $4 a$ ) it may be possible that changes in these nucleotides rather than GTP are significant for initiation of sporulation. This possibility is, however, ruled out since pool sizes of both ATP and CTP changed only slightly if cells were treated with $0.5 \mathrm{~mm}$-decoyinine (Fig. $2 a$ ), which also produced a sporulation frequency of $60 \%$.

In contrast to these conclusions, Ensign et al. (1986) argued that sporulation of $S$. griseus is nutrient-independent since cells sporulate in the presence of excess glucose, ammonium ions and phosphate. Since the medium used contained only $0.02 \%$ Casamino acids, it is possible that the cells maintained a low GTP pool even during exponential growth, as shown in the present study. Cells of S. griseus growing in a variety of synthetic media were found to have GTP pools only one-seventh to one-third the size of those of cells growing in nutritionally rich media (unpublished observations). Conceivably, $S$. griseus is unable to produce enough GTP in nutritionally poor media, so that the resulting low GTP pool size would allow triggering of sporulation of young cells at a relatively high frequency.

The decrease in GTP pool size caused by decoyinine addition was effective in initiating submerged spore formation in nutritionally rich medium, in which sporulation is normally suppressed. Although A-factor alone could not initiate submerged spore formation in the presence of excess nutrients (Fig. 1), it revealed a remarkable synergistic effect when added before decoyinine (unpublished observation). A-factor may therefore play a role in adjusting the cell physiology to receive and transmit the initial metabolic signal (i.e. the decrease in GTP) to cause eventual expression of differentiation genes. The pool size of GTP appears to be a general signal related to initiation of morphological differentiation in a number of micro-organisms, including the genera Bacillus (Lopez et al., 1981; Ochi et al., 1981), Streptomyces (Ochi, 1986a), and Saccharomyces (Freese et al., 1984).

The author acknowledges M. Kohsaka and M. Okuhara for their encouragement to proceed with this study.

\section{REFERENCES}

CASHEL, M. (1975). Regulation of bacterial ppGpp and pppGpp. Annual Review of Microbiology 29, 301-318.

DIXON, M. \& WeBB, E. C. (1964). In Enzymes, 2nd edn. London, New York \& Toronto: Longmans, Green.

ENSign, J. C., McBride, M. J., Stoxen, L. J., Bertinuson, A., Pomplun, M. \& Ho, A. (1986). The life cycle of Streptomyces: germination and properties of spores and regulation of sporulation. In Biological, Biochemical and Biomedical Aspects of Actinomycetes, pp. 777-790. Sixth International Symposium on Actinomycete Biology, 1985. Edited by G. Szabo, S. Biro \& M. Goodfellow. Budapest, Hungary: Akademiai Kiado.

Freese, E. B., Olempska-Beer, Z., Hartig, A. \& FREESE, E. (1984). Initiation of meiosis and sporulation of Saccharomyces cerevisiae by sulfur or guanine deprivation. Developmental Biology 102, 438-451.

Gallant, J. A. (1979). Stringent control in E. coli. Annual Review of Genetics 13, 393-415.

Gallant, J., IRR, J. \& Cashel, M. (1971). The mechanism of amino acid control of guanylate and adenylate biosynthesis. Journal of Biological Chemistry 246, 5812-5816.
IsHII, K. \& SHIIO, I. (1968). Regulation of purine ribonucleotide synthesis by end product inhibition. Journal of Biochemistry 63, 661-669.

KENDRICK, K. E. \& ENSIGN, J. C. (1983). Sporulation of Streptomyces griseus in submerged culture. Journal of Bacteriology 155, 357-366.

KHOKHLOV, A. S. (1986). Actinomycete autoregulators. In Biological, Biochemical and Biomedical Aspects of Actinomycetes, pp. 791-798. Sixth International Symposium on Actinomycete Biology, 1985. Edited by G. Szabo, S. Biro \& M. Goodfellow. Budapest, Hungary: Akademiai Kiado.

Lopez, J. M., Marks, C. L. \& Freese, E. (1979). The decrease in guanine nucleotides initiates sporulation of Bacillus subtilis. Biochimica et biophysica acta 587, 238-252.

Lopez, J. M., Dromerick, A. \& Freese, E. (1981). Response of guanosine $5^{\prime}$-triphosphate concentration to nutritional changes and its significance for Bacillus subtilis sporulation. Journal of Bacteriology 146, 605-613.

MagasaniK, B. (1963). Synthesis and reduction of GMP. Methods in Enzymology 6, 106-111. 
OCHI, K. (1986a). A decrease in GTP content is associated with aerial mycelium formation in Streptomyces MA406-A-1. Journal of General Microbiology 132, 299-305.

OCHI, K. (1986b). Occurrence of the stringent response in Streptomyces sp. and its significance for the initiation of morphological and physiological differentiation. Journal of General Microbiology 132, 2621 2631.

OCHI, K. (1987). A rel mutation abolishes the enzyme induction needed for actinomycin synthesis by Streptomyces antibioticus. Agricultural and Biological Chemistry 51, 829-835.

Ochi, K. Kandala, J. C. \& Freese, E. (1981). Initiation of Bacillus subtilis sporulation by the stringent response to partial amino acid deprivation. Journal of Biological Chemistry 256, 6866-6875.

Powell, G., Rajagopalan, K. V. \& Handler, P. (1969). Purification and properties of inosinic acid dehydrogenase from Escherichia coli. Journal of Biological Chemistry 244, 4793-4797.

Smith, I., Paress, P., Gabane, K. \& Dubnau, E. (1980). Genetics and physiology of the rel system of Bacillus subtilis. Molecular and General Genetics 178, 271-279.

Wu, T.-W. \& Scrimgeour, K. G. (1973). Properties of inosinic acid dehydrogenase from Bacillus subtilis. II. Kinetic properties. Canadian Journal of Biochemistry 51, 1391-1398. 